\title{
Development of TaqMan Quantitative PCR Assays for Duplex Detection of Dirofilaria immitis COIand Dog GAPDH from Infected Dog Blood
}

\author{
In Young $\mathrm{Oh}^{1}$, Kyung Tae Kim ${ }^{2}$, Sun-Yeong Gwon ${ }^{1,4}$, Ho Joong Sung ${ }^{1,3}$ \\ ${ }^{1}$ Department of Biomedical Laboratory Sciences, College of Health Science, Eulji University, Seongnam, Korea \\ ${ }^{2}$ ALPHAGENE Co., Ltd., Singu University, Business Incubation Center, Seongnam, Korea \\ ${ }^{3}$ BK21 Plus Program, Department of Senior Healthcare, Graduate School, Eulji University, Daejeon, Korea \\ ${ }^{4}$ Department of Biomedical Laboratory Science, College of Health Sciences, Yonsei University, Wonju, Korea
}

\section{심장사상충에 감염된 개 혈액에서 Dirofilaria immitis의 $C O /$ 와 개의 GAPDH를 이중 검출하기 위한 정량적 TaqMan PCR 분석법의 개발}

\author{
오인영 ${ }^{1}$, 김경태 ${ }^{2}$, 권선영 ${ }^{1,4}$, 성호중 ${ }^{1,3}$ \\ ${ }^{1}$ 을지대학교 임상병리학과, ${ }^{2}$ (주알파젠, ${ }^{3}$ 을지대학교 대학원 시니어헬스케어학과, ${ }^{4}$ 연세대학교 임상병리학과
}

\begin{abstract}
Dirofilaria immitis ( $D$. immitis) is a filarial nematode that causes cardiopulmonary dirofilariasis in dogs. In the late stages of infection, infected dogs show one or more symptoms and advanced heart disorder with perivascular inflammation. To detect $D$. immitis specifically and efficiently in the early stages of infection, a duplex TaqMan qPCR assay was developed based on previous studies using primers and probes specialized to detect $D$. immitis cytochrome coxidase subunit I $(C O I)$ and dog glyceraldehyde-3-phosphate dehydrogenase $(G A P D H)$. As positive controls, plasmid DNAs were constructed from D. immitis COI or dog GAPDH and a TA-cloning vector. Simplex and duplex TaqMan qPCR assays were performed using the specific primers, probes, and genomic or plasmid DNA. The duplex reaction developed could detect $D$. immitis $C O /$ and dog GAPDH in the same sample simultaneously after optimization of the primer concentrations. The limit of detection was 25 copies for the simplex and duplex assays, and both showed good linearity, high sensitivity, and excellent PCR efficiency. The duplex assays for pathogen detection reduce the costs, labor, and time compared to simplex reactions. Therefore, the duplex TaqMan qPCR assay developed herein will allow efficient $D$. immitis detection and quantification from a large number of samples simultaneously.
\end{abstract}

Key words: Dirofilaria immitis, Duplex detection, TaqMan quantitative real-time PCR

This is an Open Access article distributed under the terms of the Creative Commons Attribution Non-Commercial License (http://creativecommons.org/licenses/by-nc/4.0) which permits unrestricted non-commercial use, distribution, and reproduction in any medium, provided the original work is properly cited.

Copyright ( 2019 The Korean Society for Clinical Laboratory Science. All rights reserved.
Corresponding author: Ho Joong Sung Department of Biomedical Laboratory Sciences, College of Health Science, Eulji University, 553 Sanseongdea-ro, Soojeong-gu, Seongnam 13135, Korea

Tel: $82-31-740-7438$

Fax: 82-31-740-7425

E-mail: hjsung@eulji.ac.kr

ORCID: https://orcid.org/0000-0002-5614-1350

Received: February 8, 2019

Revised: February 17, 2019

Accepted: February 18, 2019

\section{INTRODUCTION}

Dirofilaria immitis (D. immitis) is a filarial nematode that causes heartworm disease in canines, felines, various wild mammals, and some human populations. Mosquitoes are the major vectors in the accidental infection of $D$. immitis 
in tropical, subtropical, and some temperate regions. With progressing globalization and climate change, the incidence of $D$. immitis infection is increasing [1-10].

The larvae of $D$. immitis develop in the mosquito at temperatures between 18 and $34^{\circ} \mathrm{C}$ before transmission to the new final host. The larvae remain in the blood until they reach the adult stage, and then they transfer to the heart, where the adult worms cause cardiopulmonary dirofilariasis. Cardiopulmonary dirofilariasis leads to immunopathological and mechanical events associated with progressive damage to the pulmonary blood vessels, the parenchyma, and the right side of the heart and with pathological relaxation of the artery wall, endarteritis, and perivascular inflammation [1-3, 7, 11-13].

Widely used methods for $D$. immitis diagnosis include microscopic morphological examination and antigen detection by immunochromatography or enzyme-linked immunosorbent assay. However, these methods have important limitations. Morphological assays have limited sensitivity and require considerable expertise to distinguish among filarial parasite species because of their rather similar morphology. In addition, antigen detection methods target antigens released from the adult female worm's reproductive tract and produce false-negative results during the first $5 \sim 8$ months of infection due to low worm counts, immature infections, and all-male infections [3-5, 10-12, 14]. To overcome these limitations, molecular detection by PCR is being developed.

In our previous study, we designed and confirmed primers for detection of $D$. immitis cytochrome c oxidase subunit I (COI) and Canis lupus familiaris (dog) glyceraldehyde-3-phosphate dehydrogenase (GAPDH). In addition, we designed a TaqMan probe to specifically detect $D$. immitis COI through quantitative real-time PCR (qPCR) [15]. To extend our previously developed assays, in this study we developed a duplex TaqMan qPCR assay using the previously designed primers and probe and a newly designed dog GAPDH probe.

\section{MATERIALS AND METHODS}

\section{Primers and probes}

The D. immitis and dog genome sequences were obtained from GenBank. The primers and probes for the detection of specific gene regions were designed based on a highly conserved region of the D. immitis COI gene (EU159111.1) (150 bp; forward: ATT GGG TGC CCC TGA AAT GG; reverse: CCC TCT ACA CTC AAA GGA GGA) and the dog GAPDHgene (NM_001003142.1) (106 bp; forward: CAT GTT TGT GAT GGG CGT GAA; reverse: GAT GAC TTT GGC TAG AGG AGC). The primer specificities were evaluated based on multiple sequence alignment, and the corresponding TaqMan probes were designed between the fragments. The probe targeting $D$. immitis $C O I$ was labeled with 6-carboxy-fluorescein (FAM, excitation wavelength $494 \mathrm{~nm}$, emission wavelength $521 \mathrm{~nm}$ ) at the 5'-end and ZEN ${ }^{\mathrm{TM}}$-Iowa Black ${ }^{\mathrm{R}} \mathrm{FQ}$ quencher at the $3^{\prime}$-end. To detect dog GAPDH as an internal control, the TaqMan probe was labeled with hexachlorofluorescein (HEX, excitation wavelength $538 \mathrm{~nm}$, emission wavelength 555 $\mathrm{nm}$ ) at the $5^{\prime}$-end and $\mathrm{ZEN}^{\mathrm{TM}}$-Iowa Black ${ }^{\mathbb{R}} \mathrm{FQ}$ quencher at the $3^{\prime}$-end. All primers and probes used in this study were synthesized by Integrated DNA Technologies (Coralville, IA, USA).

\section{Extraction of genomic DNA from dog blood samples}

D. immitis-infected blood samples isolated from infected random source dogs were gifted from Seoul National University, Republic of Korea. Peripheral blood samples from healthy volunteers and uninfected dogs were used as negative controls. All animal experiments were in accordance with the guidelines of Eulji university animal care and use committee. Genomic DNA (gDNA) from blood samples collected in ethylenediaminetetraacetic acid (EDTA) tubes was extracted using the QIAamp DNA Mini Kit (Qiagen, Hilden, Germany) according to the manufacturer's protocol. The concentration of gDNA was determined with a NanoDrop spectrophotometer (ThermoFisher Scientific, Sunnyvale, CA, USA). 


\section{Preparation of plasmid DNA}

PCR products amplified using the primers were purified and inserted into pLUG-Prime ${ }^{\circledR}$ TA-cloning vectors (iNtRON Biotechnology, Republic of Korea), and the plasmid DNA (pDNA) was cloned. The DNA copy number was estimated based on the molecular weight of the $D$. immitis $\mathrm{pDNA}$ :

copy number $=$
amount of ds DNA $(\mathrm{ng}) \times 3.0221 \times 10^{23}($ molecules $/$ mole $)$

length of ds DNA $\times 660(\mathrm{~g} / \mathrm{mole}) \times 1 \times 10^{9}(\mathrm{ng} / \mathrm{g})$

\section{TaqMan $\mathrm{qPCR}$ amplification}

TaqMan qPCR was performed with the primers and probes described above. The PCR mixture was prepared with $1 \times$ TaqMan Master Mix (Applied Biosystems, Foster City, CA, USA), with the concentrations of primers, probes, and pDNA or gDNA adjusted for each experiment. The PCR protocol included a uracil-N-glycosylase incubation step at $50^{\circ} \mathrm{C}$ for $2 \mathrm{~min}$, an initial denaturation step at $95^{\circ} \mathrm{C}$ for $10 \mathrm{~min}$, and $40 \mathrm{cycles}$ of denaturation at $95^{\circ} \mathrm{C}$ for $15 \mathrm{sec}$ and annealing and extension at $60^{\circ} \mathrm{C}$ for $1 \mathrm{~min}$. All amplification reactions were performed on a
StepOnePlus ${ }^{\mathrm{TM}}$ instrument (Applied Biosystems, Foster City, CA, USA) in a total volume of $20 \mu \mathrm{L}$. All analyses were performed in triplicate. Three samples without DNA were routinely included as a no-template control. The PCR efficiency was calculated from the dilution factor and slope of the trend line as follows:

$$
\text { PCR efficiency }=-1+\text { dilution } \text { factor }^{(-1 / \text { slope })}
$$

\section{RESULTS}

\section{Optimization of duplex reaction}

Because primer sets compete for reagents such as dNTPs and polymerase, the working concentrations of the primers were optimized for the duplex reactions. With a 1:1 ratio of $D$. immitis COIand dog GAPDH primers, the $\mathrm{Ct}$ value of $D$. immitis $C O I$ was much greater than the true $\mathrm{Ct}$ value seen for simplex reactions (data not shown). Therefore, we varied the concentrations of $\operatorname{dog} G A P D H$ primers and probe with fixed concentrations of $D$. immitis COI primers $(500 \mathrm{nM})$ and probe $(250 \mathrm{nM})$. The optimized ratio of primer concentrations between $D$. immitis COI and dog GAPDHwas 10:1 (Figure 1).
A

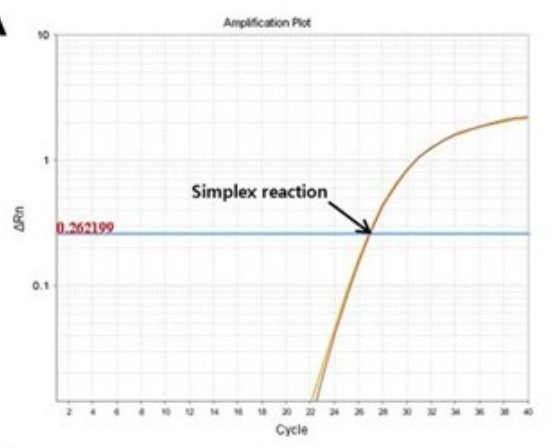

c

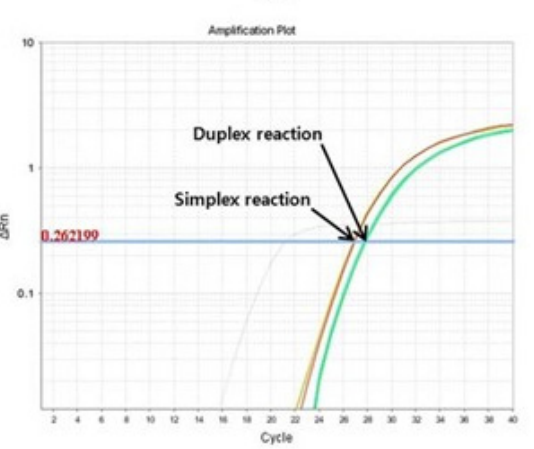

B

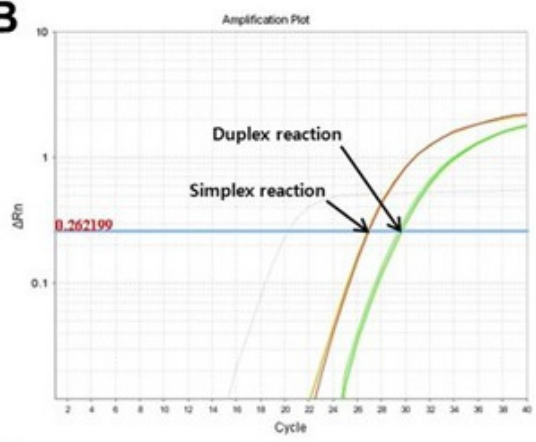

D

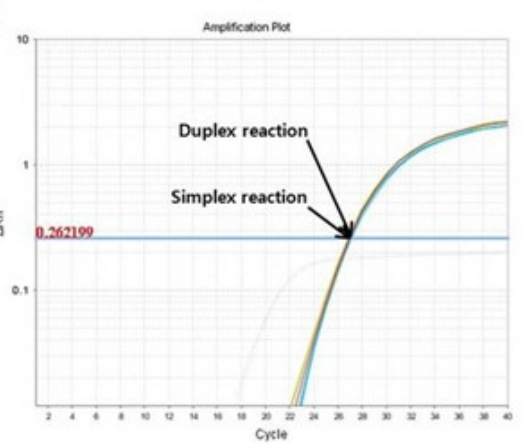

Figure 1. Optimization of duplex TaqMan qPCR. (A) Simplex reactionamplified $D$. immitis COI, FAM only; $500 \mathrm{nM}$ D. immitis CO/ primers and $250 \mathrm{nM}$ probe. (B D) Merged plots of the amplification, simplex, and duplex reactions. All of the simplex reaction plots are the same as in (A). Duplex reactions were amplified with $D$. immitis COI, FAM, and HEX. The concentrations of $D$. immitis COI primers $(500 \mathrm{nM}), D$. immitis COI probe $(250 \mathrm{nM})$ and $\operatorname{dog}$ GAPDH probe (100 nM) were fixed, and that of dog GAPDH primers was varied as follows: (B) $150 \mathrm{nM}$, (C) $100 \mathrm{nM}$, and (D) $50 \mathrm{nM}$. All amplification reactions were performed using $100 \mathrm{ng}$ genomic DNA extracted from $D$. immitis-infected dog blood. 


\section{Efficiency of simplex and duplex TaqMan qPCR assays}

To test the efficiency of the duplex reaction, simplex and duplex reactions were compared. Ct values analyzed by linear regression analysis showed good linearity (Figure 2). In the detection of $D$. immitis $C O I$, the fit parameters for the simplex reaction were $\mathrm{R}^{2}=0.9981$ and slope $=-3.1424$ with $108.1 \%$ PCR efficiency, and those of the duplex reaction were $\mathrm{R}^{2}=0.9967$ and slope $=-3.1868$ with $106.0 \%$ PCR efficiency. For detection of $\operatorname{dog} G A P D H$, the fit parameters for the simplex reaction were $\mathrm{R}^{2}=0.9929$ and slope $=-3.2085$ with 105.0\% PCR efficiency, and those for the duplex reaction were $R^{2}=0.9948$ and slope $=-3.2293$ with 104.0\% PCR efficiency.

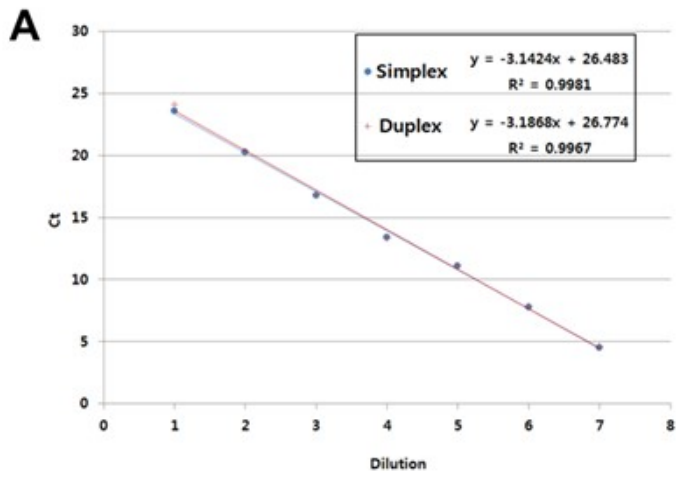

B

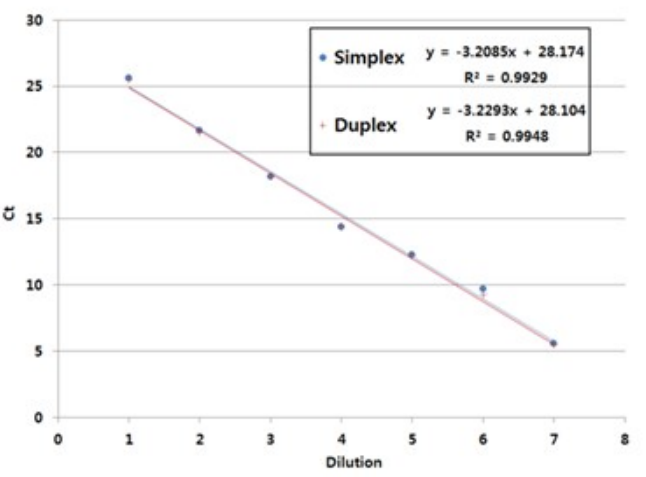

Figure 2. Comparison of simplex and duplex reactions. (A) $D$. immitis CO/ detection. Simplex: FAM only; $500 \mathrm{nM}$ primers, 250 $\mathrm{nM}$ probe, and serially diluted $D$. immitis $\mathrm{CO} / \mathrm{pDNA}\left(3 \times 10^{10}\right.$ to $3 \times 10^{4}$ copies). Duplex: FAM and HEX; D. immitis COI simplex assay components; $50 \mathrm{nM}$ primers, $25 \mathrm{nM}$ probe, and serially diluted dog GAPDH pDNA ( $3 \times 10^{10}$ to $3 \times 10^{4}$ copies). (B) Dog GAPDH detection. Simplex: HEX only; $50 \mathrm{nM}$ primers, $25 \mathrm{nM}$ probe, and serially diluted dog GAPDH pDNA $\left(3 \times 10^{10}\right.$ to $3 \times 10^{4}$ copies). Duplex: FAM and HEX; D. immitis $C O /$ duplex assay components.

\section{Limit of detection}

To determine the limit of detection, serially diluted pDNA samples were used as templates. The detection limit was 25 copies for both the simplex and duplex assays. Ct values analyzed by linear regression analysis showed good linearity even for low copy numbers (Figure 3).

\section{Clinical sample evaluation using duplex TaqMan qPCR}

Clinical samples were evaluated by duplex TaqMan qPCR assay and quantified using the standard curve (Figure 3). The results for the positive control, a sample at

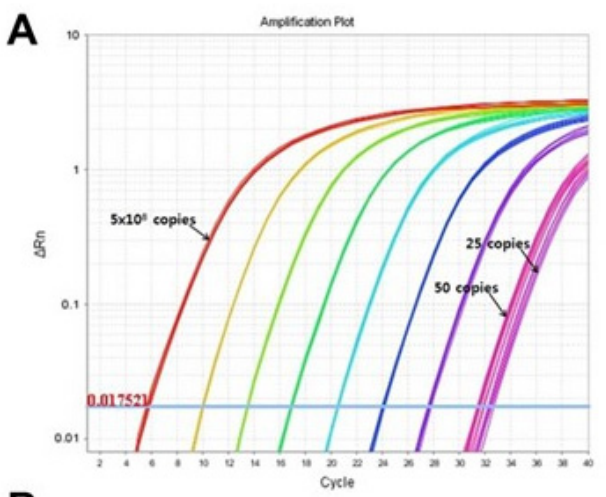

B

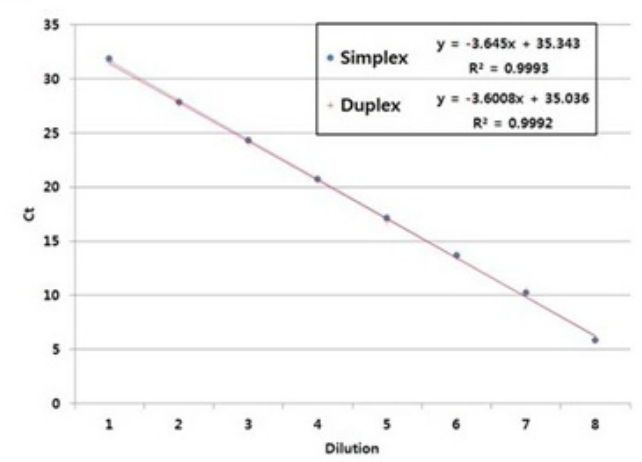

Figure 3. Limit of detection and standard curve. Eight points of a 10 -fold dilution series (from $5 \times 10^{8}$ to 50 copies of $D$. immitis COI pDNA) and 25 copies of $D$. immitis CO/ pDNA were analyzed by TaqMan qPCR for D. immitis COI (500 nM primers and $250 \mathrm{nM}$ probe) and dog GAPDH (50 nM primers and $250 \mathrm{nM}$ probe). In the duplex assay, all templates contained $5 \times 10^{5}$ copies dog GAPDH pDNA. (A) Merged image of amplification plots of simplex $(D$. immitis $C O D$ ) and duplex assay (D. immitis $C O /$ and dog GAPDH). (B) Linearity plots of $\mathrm{Ct}$ values for simplex and duplex assays. Blue circles show the $\mathrm{Ct}$ values for the simplex assay, and the blue line is the trend line for those values. Red crosses represent the $\mathrm{Ct}$ values of the duplex assay, and the red line is the trend line for those values. Both trend lines showed good linearity even at low copy numbers. 


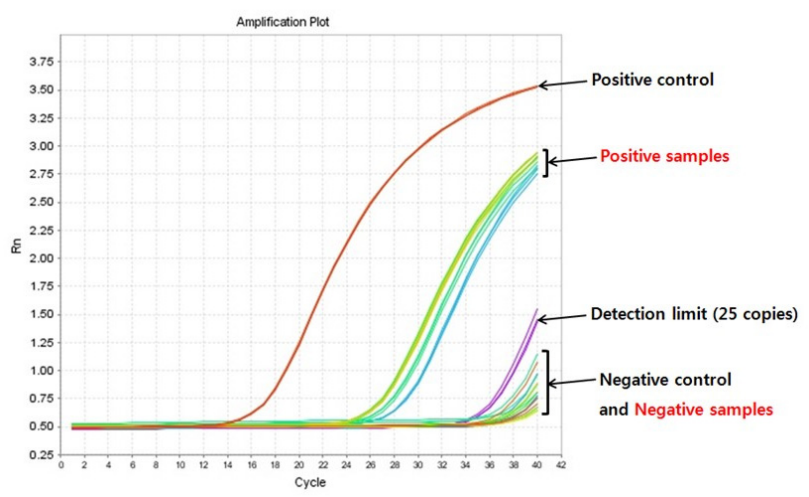

Figure 4. Clinical sample test using duplex TaqMan qPCR. Plasmid DNAs were used as positive control templates $\left(5 \times 10^{6}\right.$ copies $D$. immitis $\mathrm{CO} / \mathrm{pDNA}$ and $5 \times 10^{5}$ copies dog GAPDH pDNA), negative control templates ( 0 copies $D$. immitis $C O /$ pDNA and $5 \times 10^{5}$ copies $\operatorname{dog}$ GAPDH pDNA), and detection limit samples (25 copies $D$. immitis COI pDNA and $5 \times 10^{5}$ copies dog GAPDH pDNA). Genomic DNA (100 ng) extracted from D. immitis-infected or healthy dog blood samples was used as the template for positive and negative samples, respectively.

the detection limit, the negative control, and the positive and negative clinical samples are shown in Figure 4. The Ct value of the positive control was 14, and that of the sample at the detection limit was 34 . Ct values of the negative control and negative samples exceeded the detection limit (>36). The Ct values of positive clinical samples were 24 $\sim 26$, which were corresponded to the $\mathrm{Ct}$ values of $5 \times 10^{3}$ copies for the standard curve.

\section{DISCUSSION}

Cardoso et al. [11] reported that suspect or symptomatic dogs show one or more clinical features, including hair loss, appetite loss, skin ulcers, cyanosis, dermatitis, diarrhea, dry chronic cough, difficultly breathing, nosebleed, exercise intolerance, hemorrhagic disorders, hyperthermia, joint inflammation, limping, lethargy, lymph node enlargement, neurologic signs, ocular lesions, bent claws, pale mucous membranes, excessive thirst, vomiting, weakness, and weight loss. Healthy or asymptomatic dogs had no signs or historical abnormalities. Nationally, 3.6\% of healthy dogs tested positive for $D$. immitis antigen; however, in some regions, up to $40 \%$ of healthy dogs were $D$. immitis antigen-positive. Thus, many dogs infected with $D$. immitis remain asymptomatic for several months or a few years [11].

Development of methods for molecular diagnosis of $D$. immitis infection is needed to detect parasites from the early stage of infection easily, accurately, and efficiently. qPCR assays provide high sensitivity and specificity and require less time and labor to complete than conventional PCRs [16-21]. In addition, duplex qPCR assays can detect two genes in the same sample simultaneously and are therefore more cost-effective than simplex assays for detecting each gene separately. Furthermore, duplex qPCR assays can accommodate a large number of samples simultaneously [17].

In this study, we developed duplex TaqMan qPCR assays to detect and quantify the $D$. immitis-specific COI gene fragment in dog blood simultaneously with amplification and detection of the dog GAPDH gene as the internal control. The specificity and applicability of the method were confirmed in our previous study using multiple sequence alignment from the GenBank DNA database. To optimize the duplex reaction, primer concentrations were varied, and the optimized conditions yielded specificities and sensitivities similar to those of the simplex assays.

The D. immitis COI detection limit of duplex qPCR assays was 20 copies lower than that of previously developed assays [15]. The low detection limit of the duplex qPCR assay provides a clinically useful tool to identify pathogens with a low infection rate or in the early stage of infection, thereby reducing the potential for false-negative results [17]. In addition, these results showed overall superior performance compared with our previously developed assays using end-point PCR and real-time PCR. TaqMan qPCR-based clinical diagnostics for pathogen detection provide clear results even for samples contaminated with other pathogens or impurities because the primers and probes used in the assays are specific to the D. immitis COI gene region and broadly covered $54.7 \%$ of the gene sequence (150 bp) without cross-reaction with gDNA from dog blood.

Toward overall therapeutic monitoring, this study allows for additional development of multiple-pathogen 
detection using specific primers and probes in the same sample. Such an extension of the method warrants further investigation.

\section{요 약}

Dirofilaria immitis (D. immitis)는 개의 심폐사상충증을 일 으키는 선형사상충이다. 이 기생충에 감염된 개는 감염 후기 단 계에서 하나 이상의 증상과 혈관 주위의 염증을 동반한 심화된 심장 질환을 보인다. 감염 초기단계에 특이적이고 효율적으로 D. immitis를 검출하기 위해서, 선행연구에서 밝혀낸 $D$. immitis의 cytochrome c oxidase subunit I ( $C O I)$ 와 개의 glyceraldehyde-3-phosphate dehydrogenase (GAPDH)를 검출하는 특이적인 프라이머와 프로브를 이용하여 이중 TaqMan qPCR 방법을 개발했다. 양성 대조군인 플라스미드 유 전자는 $\mathrm{TA}$-cloning vector와 D. immitis의 CO나 개의 $G A P D H$ 로 구성되었다. 단일과 이중 TaqMan qPCR 방법은 특 이적인 프라이머와 프로브, 그리고 게놈 유전자나 플라스미드 유전자로 수행했다. 프라이머의 농도를 최적한 후, 본 연구에서 개발한 이중 반응은 D. immitis의 COI와 개의 $G A P D H$ 를 동일 시료에서 동시에 검출했다. 검출 한계는 단일과 이중 방법 모두 25 copies였고, 두 방법 모두 좋은 선형성과 높은 민감도, 그리 고 우수한 PCR 효율을 보여주었다. 병원체를 검출하기 위한 이 중 방법은 단일 방법에 비해 비용과 노동력, 시간이 적게 든다. 따라서 이중 TaqMan qPCR 방법의 개발은 많은 수의 시료로부 터 동시에 효율적으로 D. immitis 검출과 정량이 가능하게 할 것이다.

Acknowledgements: We thank Prof. Byeong Chun Lee, Seoul National University, Republic of Korea for providing dog blood samples.

\section{Conflict of interest: None}

Author's information (Position): Oh IY ${ }^{1}$, Researcher; Kim KT ${ }^{2}$, Researcher; Gwon SY ${ }^{1,4}$, Graduate student; Sung $\mathrm{HJ}^{1,3}$, Professor.

\section{REFERENCES}

1. Watts KJ, Courteny CH, Reddy GR. Development of a PCR- and probe-based test for the sensitive and specific detection of the dog heartworm, Dirofilaria immitis, in its mosquito intermediate host. Mol Cell Probes. 1999;13:425-430.
2. Kronefeld M, Kampen H, Sassnau R, Werner D. Molecular detection of Dirofilaria immitis, Dirofilaria repens and Setaria tundra in mosquitoes from Germany. Parasit Vectors. 2014; $7: 30$.

3. Rojas A, Rojas D, Montenegro VM, Baneth G. Detection of Dirofilaria immitis and other arthropod-borne filarioids by an HRM real-time qPCR, blood-concentrating techniques and a serological assay in dogs from Costa Rica. Parasit Vectors. 2015;8:170.

4. Xu D, Zhang J, Shi Z, Song C, Zheng X, Zhang Y, et al. Molecular detection of vector-borne agents in dogs from ten provinces of China. Parasit Vectors. 2015;8:501.

5. Oi M, Sato Y, Nakagaki K, Nogami S. Detection of Dirofilaria immitis DNA in host serum by nested PCR. Parasitol Res. 2015;114:3645-3648.

6. Khedri J, Radfar MH, Borji H, Azizzadeh M, Akhtardanesh B. Canine heartworm in southeastern of Iran with review of disease distribution. Iran J Parasitol. 2014;9:560-567.

7. Fu Y, Lan J, Wu X, Yang D, Zhang Z, Nie H, et al. Expression of translationally controlled tumor protein (TCTP) gene of Dirofilaria immitis guided by transcriptomic screening. Korean J Parasitol. 2014;52:21-26.

8. Rossi MI, Aguiar-Alves F, Santos S, Paiva J, Bendas A, Fernandes O, et al. Detection of Wolbachia DNA in blood from dogs infected with Dirofilaria immitis. Exp Parasitol. 2010;126: 270-272.

9. Nuchprayoon S, Junpee A, Poovorawan Y, Scott AL. Detection and differentiation of filarial parasites by universal primers and polymerase chain reaction-restriction fragment length polymorphism analysis. Am J Trop Med Hyg. 2005;73:895-900.

10. Furtado AP, Do Carmo ES, Giese EG, Vallinoto AC, Lanfredi RM, Santos JN. Detection of dog filariasis in Marajo Island, Brazil by classical and molecular methods. Parasitol Res. 2009;105: 1509-1515.

11. Cardoso L, Mendao C, Madeira de Carvalho L. Prevalence of Dirofilaria immitis, Ehrlichia canis, Borrelia burgdorferi sensu lato, Anaplasma spp. and Leishmania infantum in apparently healthy and CVBD-suspect dogs in Portugal--a national serological study. Parasit Vectors. 2012;5:62.

12. Schnyder M, Deplazes P. Cross-reactions of sera from dogs infected with Angiostrongylus vasorum in commercially available Dirofilaria immitis test kits. Parasit Vectors. 2012;5:258.

13. Masetti A, Rivasi F, Bellini R. Mosquito-based survey for the detection of flaviviruses and filarial nematodes in Aedes albopictus and other anthropophilic mosquitoes collected in northern Italy. New Microbiol. 2008;31:457-465.

14. Mazzariol S, Cassini R, Voltan L, Aresu L, Frangipane di Regalbono A. Heartworm (Dirofilaria immitis) infection in a leopard (Panthera pardus pardus) housed in a zoological park in north-eastern Italy. Parasit Vectors. 2010;3:25-25.

15. Oh IY, Kim KT, Jun JH, Shin J-H, Sung HJ. Development of real-time PCR assays for detection of Dirofilaria immitis from infected dog blood. Korean J Clin Lab Sci. 2016;48:88-93.

16. De Gregorio E, Roscetto E, Iula VD, Martinucci M, Zarrilli R, Di Nocera PP, et al. Development of a real-time PCR assay for the rapid detection of Acinetobacter baumannii from whole blood samples. New Microbiol. 2015;38:251-257. 
17. Leal CA, Carvalho AF, Leite RC, Figueiredo HC. Development of duplex real-time PCR for the detection of WSSV and PstDV1 in cultivated shrimp. BMC Vet Res. 2014;10:150.

18. Liu T, Yang B, Song X, Wang X, Yuan Y, Liu L, et al. Detection and quantification of hepatopancreatic parvovirus in penaeid shrimp by real-time PCR assay. J Invertebr Pathol. 2013;114: 309-312.

19. Liu CM, Kachur S, Dwan MG, Abraham AG, Aziz M, Hsueh PR, et al. FungiQuant: a broad-coverage fungal quantitative real-time PCR assay. BMC Microbiol. 2012;12:255.

20. Li K, Gao H, Gao L, Qi X, Qin L, Gao Y, et al. Development of TaqMan real-time PCR assay for detection and quantitation of reticuloendotheliosis virus. J Virol Methods. 2012;179:402-408.

21. Qu S, Shi Q, Zhou L, Guo Z, Zhou D, Zhai J, et al. Ambient stable quantitative PCR reagents for the detection of Yersinia pestis. PLoS Negl Trop Dis. 2010;4:e629. 